\title{
Aplikasi Manajemen Aset Berbasis Web Pada SMA Hang Tuah 4 Surabaya
}

\author{
Rahmat Julianto Putra ${ }^{1}$, Endra Rahmawati ${ }^{2}$, Nunuk Wahyunigtyas ${ }^{3}$ \\ ${ }^{1,2)}$ Program Studi S1 Sistem Informasi, Universitas Dinamika \\ ${ }^{3}$ Program Studi D3 Sistem Informasi, Universitas Dinamika \\ Email : ${ }^{1)} 18410100267 @$ dinamika.ac.id ${ }^{1}$,rahmawati@dinamika.ac.id ${ }^{2}$, nunuk@dinamika.ac.id ${ }^{3}$
}

\begin{abstract}
Abstrak: Inventaris aset tetap yang ada di SMA Hang Tuah 4 Surabaya dikelola oleh Bagian Wakasapras (Wakil Kepala Sekola Sarana dan Prasarana). Pendataan aset yang dilakukan oleh Wakasapras terdiri dari penerimaan aset, perbaikan aset, perawatan asset dan penghapusan asset. Semua proses terseut saat ini masih dilakukan secara manual yaitu dengan dicatat di dalam buku dan di Microsoft Excel untuk kemudian disimpan ke dalam flashdisk. Proses pencataan seperti itu membutuhkan waktu untuk melakukan pencarian asset dan kesulitan mengetahui data asset apa saja yang perlu dilakukan perawatan/perbaikan asset. Hal ini mengakibatkan jumlah kisaran biaya yang harus dianggarkan oleh pihak sekolah untuk keperluan pengelolaan asset sulit untuk diketahui. Oleh karena itu, dibutuhkan sebuah sistem Aplikasi Manajemen Aset Berbasis Web yang dapat mengatasi proses pengelolaan asset dan menghasilkan laporan hasil pengelolaan asset secara periodik setiap bulan. Hasil pengujian aplikasi tersebut $92.8 \%$ dapat berjalan dengan baik secara uji coba fungsional menggunakan Blak Box Testing.
\end{abstract}

Kata Kunci: Aplikasi, Manajemen Aset, Aset Tetap.

\begin{abstract}
The inventory of fixed assets in SMA Hang Tuah 4 Surabaya is managed by the Wakasapras Section (Vice Head of School of Facilities and Infrastructure). Asset data collection carried out by Wakasapras consists of asset receipts, asset repairs, asset maintenance and asset write-offs. All of these processes are still done manually, namely by being recorded in books and in Microsoft Excel and then saved to a flash disk. Such a recording process requires time to search for assets and it is difficult to find out what asset data need asset maintenance/repair. This causes the amount of the range of costs that must be budgeted by the school for asset management purposes is difficult to know. Therefore, we need a Web-Based Asset Management Application system that can overcome the asset management process and generate asset management reports on a monthly basis. The results of testing the application $92.8 \%$ can run well in a functional trial using Black Box Testing.
\end{abstract}

Keywords: Applications, Asset Management, Fixed Assets.

\section{PENDAHULUAN}

SMA Hang Tuah 4 Surabaya merupakan salah satu sekolah menengah yang berada di Jl. Bogowonto No. 18 Kota Surabaya, Jawa timur. Sekolah ini menyediakan berbagai fasilitas penunjang pendidikan bagi anak didiknya. Terdapat guru-guru dengan kualitas terbaik yang kompeten dibidangnya, kegiatan penunjang pembelajaran seperti ekstrakurikuler (ekskul), organisasi siswa, komunitas belajar, tim olahraga, dan perpustakaan sehingga siswa dapat belajar secara maksimal. Proses belajar dibuat senyaman mungkin bagi murid dan siswa.

Aset tetap yang ada di SMA Hang Tuah 4 Surabaya ini dikelola oleh Bagian Wakasapras (Sarana dan Prasarana). Proses Manajemen aset mencakup proses perencanaan, perancangan, pengorganisasian, penggunaan, pemeliharaan sampai penghapusan serta di dalamnya pengawasan aset. Proses ini dilakukan secara sistematis dan terstruktur selama siklus hidup aset. Manajemen aset berupaya melakukan pengoptimalisasian penggunaan aset dalam 
Rahmat Julianto Putra, dkk/ Journal of Technology and Informatics (JoTI), Vol.2, No.2, April 2021, Hal 65-71

rangka memberi manfaat dalam pemberian layanan dan pengembalian keuangan. Manajemen aset yang baik dan meminimalkan biaya, memaksimallkan ketersediaan aset, dan memaksimalkan utilisasi asset [1]. Pendataan aset yang dilakukan pada SMA Hang Tuah 4 Surabaya adalah pencatatan kode aset, pencatatan kode asal, pengelolaan aset, perbaikan aset, perawatan aset, penghapusan asset.

Penomoran Aset menggunakan nomor identifikasi barang secara unik yang dapat dimuat pada daftar persediaan barang. Beberapa lembaga/organisasional menyebutnya part number, nomor model, kode produk, kode barang, dan kode item [2]. Penomoran barang sangat penting dalam pembuatan sistem inventory barang. Apabila sistem tidak mampu mengidentifikasi barang secara unik, maka tidak akan dapat memperhitungkan aktivitas dan keberadaan dalam inventory secara efektif. Penomoran barang juga berfungsi sebagai singkatan untuk deskripsi barang. Menggunakan penomoran barang yang jauh lebih pendek justru akan mempercepat proses entri data dan pengelolaan inventory.

Untuk pengelolaan aset saat ini di SMA Hang Tuah 4 Surabaya masih manual atau ditulis di dalam buku dan sebagian juga data aset ada yang dicatat di microsoft excel dan disimpan di flashdisk apabila ada aset baru yang datang kemudian bagian wakasapras akan melakukan pendataan pengelolaan aset. Tetapi apabila masih dengan cara tulis di buku atau diketik di microsoft excel justru menimbulkan kekeliruan pada saat melakukan pencatatan pengelolaan aset, terkadang ada dua data yang sama pada saat melakukan pendataan atau kadang tidak sesuai dengan aslinya, sehingga terdapat data yang sama dengan keterangan aset yang berbeda. Untuk proses perbaikan aset, petugas sekolah akan melakukan pendataan aset yang akan diperbaiki dalam bentuk kertas yang kemudian akan diberikan kepada bagian wakasapras sebagai tanda bukti bahwa ada aset yang rusak dan harus segera diperbaiki.

Kemudian untuk proses perawatan aset, proses yang terjadi saat ini ialah belum adanya perawatan aset, untuk perawatan asetnya hanya dilakukan pada saat ada aset yang mengalami kerusakan saja. Belum adanya perawatan aset menyebabkan aset yang ada di SMA Hang Tuah 4 Surabaya menjadi cepat rusak dan mengeluarkan biaya terus menerus. Perawatan aset yang sudah dilakukan inipun masih ada yang tidak dicatat, sehingga bagian wakasapras dan petugas tidak tahu aset mana saja yang sering mengalami kerusakan dan biaya berapa yang dikeluarkan, sedangkan untuk proses penghapusan aset yang dilakukan oleh bagian wakasapras dan petugas ini melakukan memusnahkan aset yang sudah tidak layak pakai lagi atau sudah tidak berfungsi lagi untuk kebutuhan di SMA Hang Tuah 4 Surabaya. Namun terdapat masalah yang terjadi saat penghapusan aset yang dilakukan oleh bagian wakasapras dan petugas. Aset yang sudah dihapus juga masih ada yang tidak dicatat, sehingga bagian wakasapras dan petugas tidak tahu berapa jumlah aset yang sudah dihapus dan aset apa saja yang sudah dihapus.

Beberapa penelitian sejenis mengenai pengelolaan manajemen asset juga menekankan pada proses labelling/penomoran asset dan menjaga kualitas asset agar sesuai dengan nilai asetnya [3][4]. Manajemen Aset juga sering dilakukan untuk data inventaris sekolah [5][6][4][7][8].

Jika barang yang sudah rusak atau tidak layak dipakai lagi nantinnya akan disimpan di dalam gudang. Barang-barang rusak yang sudah disimpan di dalam gudang tersebut nantinya akan dicek kembali, apakah masih bisa digunakan kembali atau tidak. Jika barang tersebut sudah tidak layak dipakai lagi, maka barang tersebut akan dibuang (pengecekkan untuk barang yang masih bisa digunakan dan barang yang sudah tidak bisa digunakan). Berikut ini adalah tabel data aset tetap yang ada di SMA Hang Tuah 4 Surabaya.

Tabel 1 Data Aset Tetap SMA Hang Tuah 4 Surabaya.

\begin{tabular}{ll}
\hline Nama Aset & Jumlah \\
\hline Bangku siswa & 110 Unit \\
\hline Meja lab & 40 Unit \\
\hline Kursi lab & 85 Unit \\
\hline AC & 16 Unit \\
\hline Kursi ruang meeting & 12 Unit \\
\hline Meja kantor & 3 Unit \\
\hline Komputer lab bahasa & 38 Unit \\
\hline Komputer bantuan & 14 Unit \\
\hline
\end{tabular}

Sumber : Data Aset SMA Hang Tuah Surabaya

Berdasarkan permasalahan di atas, maka dibuatlah sebuah aplikasi manajemen aset 
Rahmat Julianto Putra, dkk/ Journal of Technology and Informatics (JoTI), Vol.2, No.2, April 2021, Hal 65-71

berbasis website pada SMA Hang Tuah 4 Surabaya untuk membantu dan memudahkan bagian wakasapras dan petugas sekolah dalam melakukan pendataan aset yang terdiri dari pencatatan kode aset, pengelolaan aset, perbaikan aset, perawatan aset, penghapusan aset. Uji coba akhir aplikasi dilakukan menggunakan Black Box Testing [9].

\section{METODE}

Tahapan penelitian pada Aplikasi Pengelolaan Manajemen Aset ini menggunakan konsep Pengembangan Perangkat Lunak SDLC Waterfall Tahapan awal adalah Communication, Planning, Modelling, Construct, dan Deployment [10].

\section{Wawancara}

Wawancara dilakukan kepada bagian Wakasapras dengan mengajukan beberapa pertanyaan untuk mengetahui apa saja kendala yang dihadapi dalam mengelola aset SMA Hang Tuah 4 Surabaya. Setelah selesai melakukan wawancara kepada bagian wakasapras (Sarana dan prasarana) di SMA Hang Tuah 4 Surabaya, kemudian peneliti mengumpulkan data yang dibutuhkan untuk pembuatan aplikasi manajemen aset yang sesuai dengan kebutuhan sekolah.

\section{Observasi}

Observasi dilakukan di SMA Hang Tuah 4 Surabaya, yang beralamat di Jalan Bogowonto No. 8 Kota Surabaya, Jawa timur dimulai pada tanggal 25 Maret 2021 sampai dengan 25 Juni 2021 untuk mendapatkan beberapa hal seperti :

a. Gambaran umum Data Aset di SMA Hang Tuah 4 Surabaya.

b. Mempelajari Proses Pengelolaan Manajemen Aset Tetap milik sekolah.

c. Mempelajari proses penyajian laporan pengelolaan asset yang dilakukan secara periodik.

\section{Identifikasi Masalah}

Berdasarkan hasil observasi dan wawancara yang dilakukan pada Bagian Wakasapras SMA Hang Tuah 4 Surabaya, terdapat masalah mengenai pencatatan asset yang tidak terstruktur sehingga mengakibatkan data antara jumlah asset di lapangan dan di buku catatan tidak sama, kesulitan melakukan penjadwalan perawatan/perbaikan asset, serta proses mendapatkan laporan pengelolaan asset yang lama saat dibutuhkan oleh Kepala Sekolah.

\section{Identifikasi Data}

Data-data yang diperlukan untuk aplikasi manajement asset tetap pada SMA Hang Tuah 4 Surabaya adalah sebagai berikut:

a. Data master user

b. Data master jenis aset

c. Data master asal aset

d. Data master lokasi asal

e. Data master aset

f. Data transaksi pengelolaan aset

g. Data transaksi perbaikan aset

h. Data transaksi perawatan aset

i. Data transaksi penghapusan aset

\section{Identifikasi Fungsi}

Fungsional aplikasi yang diperlukan sebagai berikut:

a. Pengelolaan data asset, jenis asset, asal asset, serta lokasi penyimpanan asset.

b. Pencarian data aset.

c. Pengelolaan Transaksi Penerimaan Aset, Perbaikan, Perawatan, dan Penghapusan Aset.

d. Cetak Laporan Laporan Data Aset, Laporan perbaikan asset, Laporan perawatan aset, dan Laporan penghapusan aset .

\section{Modeling}

Berdasarkan analisis sistem dari permasalahan yang dihadapi, selanjutnya akan dibuat desain dari aplikasi tersebut. Tujuan dari desain aplikasi ini adalah membuat kerangka dasar dalam melakukan implementasi ke sistem informasi yang dibuat.

Dalam perancangan sistem ini ada beberapa tahapan yang harus dilakukan, yaitu pembuatan Model Pengembangan, System Flow, Data Flow Diagram (DFD), Entity Relationship Diagram (ERD), Struktur Database, dan Desain Input dan Output dari program aplikasi ini. 


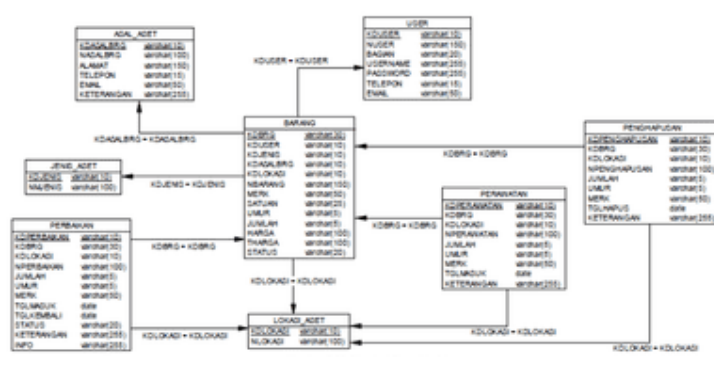

Gambar 1. Physical Data Model

\section{System Flow}

Pada proses ini data fisik asset yang diterima oleh Wakasapras maupun bagian lain yang terkait akan disimpan ke dalam database. Selanjutnya sistem akan menampilkan data yang sudah tersimpan pada tanggal tersebut.

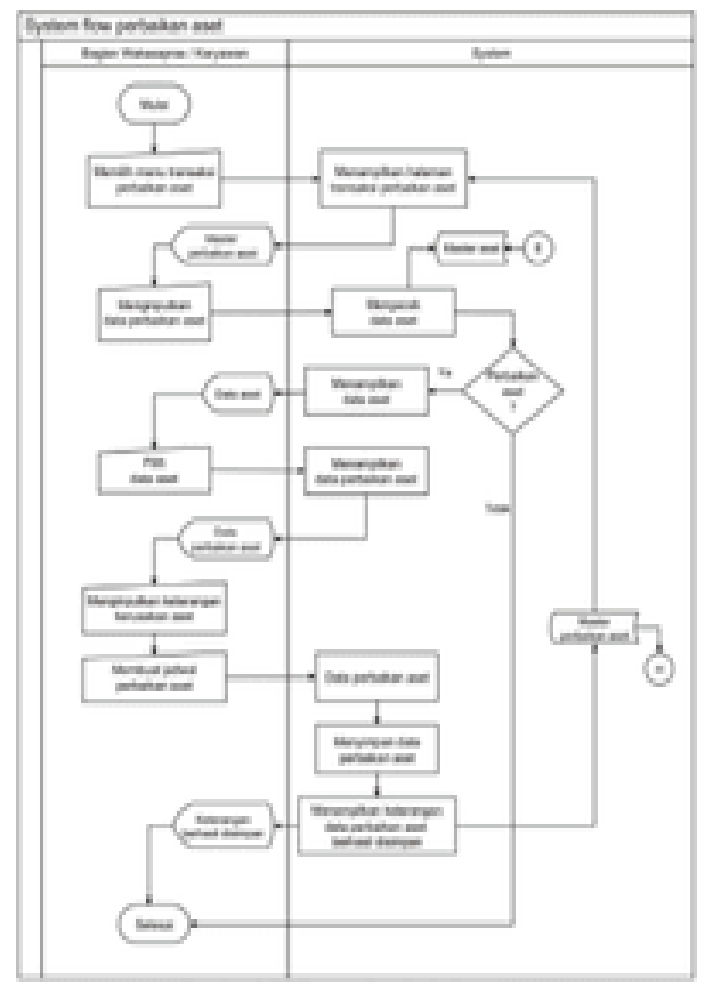

Gambar 2. Sysflow Perbaikan Aset

\section{Data Flow Diagram}

Data Flow Diagram di bawah ini menggambarkan menggambarkan terdapat 3 proses utama yang saling berhubungan, antara lain: pengelolaan data master, data transaksi dan fungsi cetak laporan.

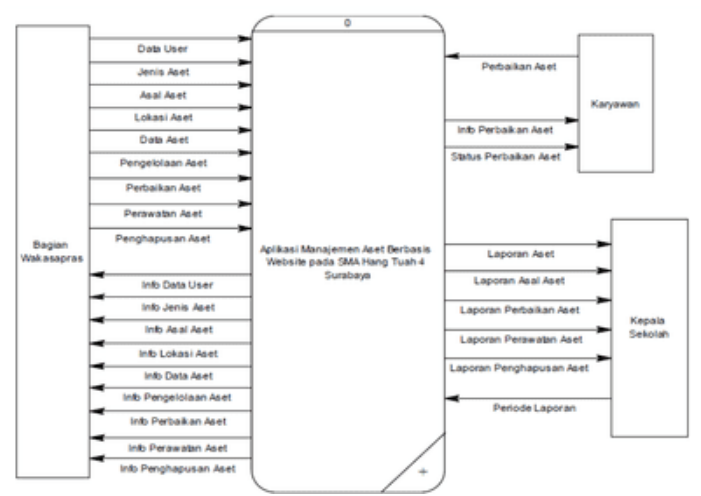

Gambar 3. Context Diagram

\section{HASIL DAN PEMBAHASAN}

Tampilan Dashboard

Form dashboard akan tampil ketika aplikasi mulai dijalankan. Pengguna dapat melihat informasi dan status asset jika dilakukan proses perawatan/perbaikan/penghapusan secara real-time.

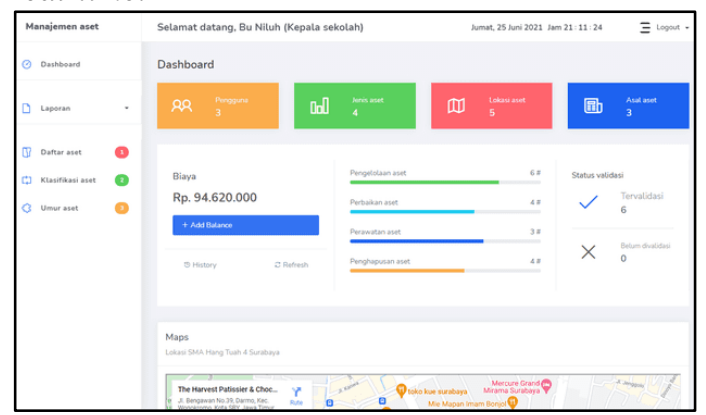

Gambar 4. Tampilan Dashboard

\section{Tampilan Form Klasifikasi Aset}

Pada tampilan halaman klasifikasi aset ini menampilkan kode aset, nama aset, merk aset, satuan aset, dan jenis aset. Pada tampilan halaman klasifikasi aset ini menampilkan aset berdasarkan jenis asetnya. Pada fitur klasifikasi aset ini kepala sekolah (user) dapat mengetahui jenis aset yang ada di SMA Hang Tuah 4 Surabaya.

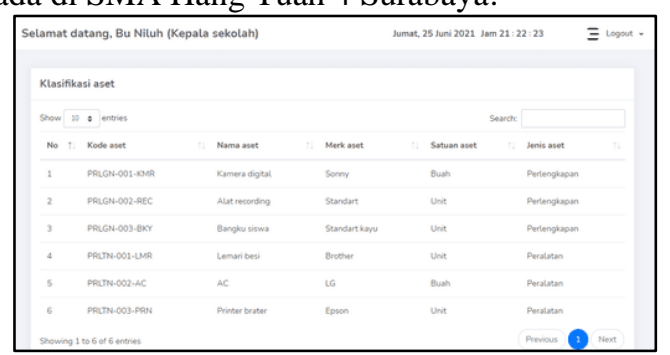

Gambar 5. Tampilan form Klasifikasi Jenis Aset. 
Rahmat Julianto Putra, dkk/ Journal of Technology and Informatics (JoTI), Vol.2, No.2, April 2021, Hal 65-71

\section{Tampilan Form Perbaikan Aset}

Pada halaman data perbaikan aset menampilkan kode perbaikan, nama aset, jumlah perbaikan, tanggal perbaikan, status perbaikan, dan aksi. Pada bagian aksi menampilkan icon detail, icon ubah, dan icon hapus. Tampilan pada halaman ini digunakan untuk menampilkan data perbaikan aset yang telah diinputkan oleh bagian wakasapras.

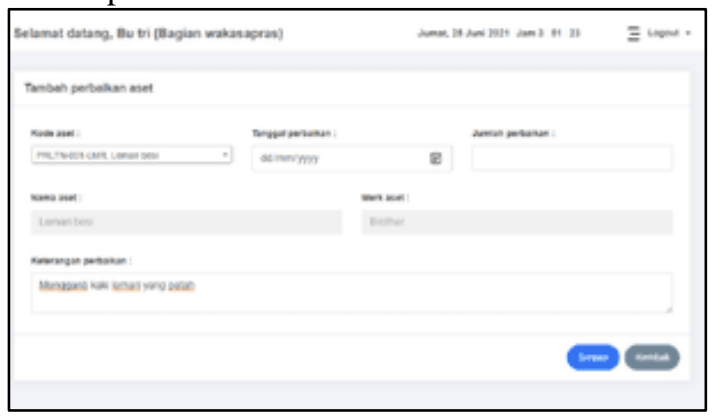

Gambar 6. Tampilan form Perbaikan Aset.

\section{Tampilan Form Perawatan Aset}

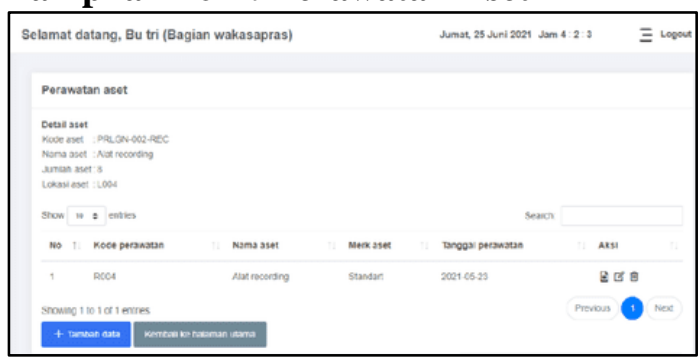

Gambar 7. Tampilan form Perawatan Aset.

Setelah tambah data di klik, maka akan berpindah halaman ke tambah perawatan aset digunakan untuk menambah perawatan aset apabila ada penambahan perawatan aset baru pada aplikasi manajemen aset berbasis website.

\section{Notifikasi Waktu Perawatan Aset}

Pada halaman daftar perawatan aset (kelompok barang) menampilkan kode aset, nama aset, lokasi aset, tahun rawat, jumlah rawat, dan aksi. Pada bagian aksi menampilkan tombol dengan keterangan "Lakukan perawatan" dan juga pada bagian atas terdapat kalimat "Waktunya Melakukan Perawatan Aset", fungsinya untuk memberikan informasi bahwa aset yang ada di SMA Hang Tuah 4 Surabaya harus dilakukan perawatan secara rutin.

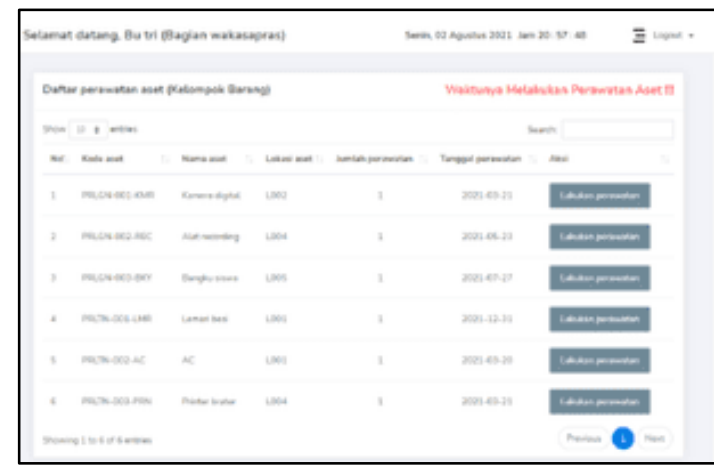

Gambar 8. Notifikasi Waktu Perawatan Aset.

\section{Tampilan Form Penghapusan Aset}

Form Penghapusan Aset terdiri dari pemilihan data asset yang akan dihapus, jumlah asset yang dihapus, kode penghapusan asset, serta tanggal penghapusan asset.

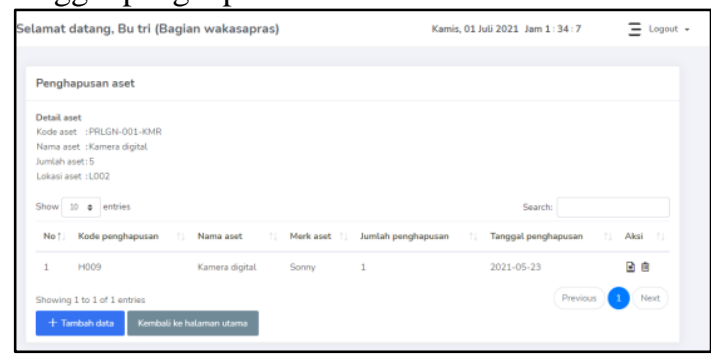

Gambar 9. Tampilan form Penghapusan Aset.

\section{Tampilan Laporan Data Aset}

Pada tampilan halaman laporan aset ini merupakan tampilan hasil dari print yang dilakukan oleh bagian Wakasapras (admin).

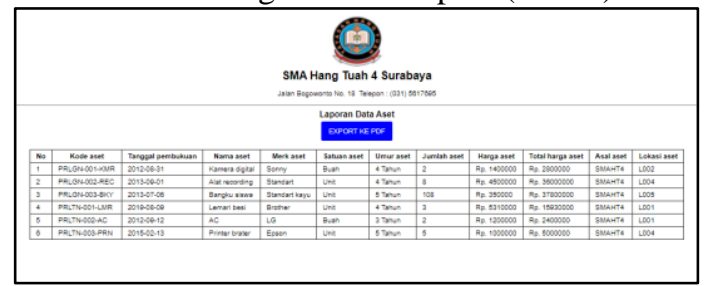

Gambar 10. Tampilan Laporan Data Aset PDF siap cetak.

\section{Pengujian Aplikasi}

Pengujian ini dilakukan di setiap tampilan dan fungsi menggunakan Black Box Testing pada aplikasi manajemen aset SMA Hang Tuah 4 Surabaya. Penjelasan untuk hasil pengujian ini dapat dilihat pada tabel 2.

Tabel 2. Pengujian Aplikasi 
Rahmat Julianto Putra, dkk/ Journal of Technology and Informatics (JoTI), Vol.2, No.2, April 2021, Hal 65-71

\begin{tabular}{|c|c|c|c|}
\hline No & Aksi & Masukkan & Status \\
\hline 1 & $\begin{array}{l}\text { Melakukan } \\
\text { login pada } \\
\text { aplikasi }\end{array}$ & $\begin{array}{l}\text { Masuk ke dalam } \\
\text { tampilan halaman } \\
\text { dashboard }\end{array}$ & Berhasil \\
\hline 2 & $\begin{array}{l}\text { Cek hak } \\
\text { akses } \\
\text { pengguna }\end{array}$ & $\begin{array}{l}\text { Hak akses setiap } \\
\text { pengguna berbeda } \\
\text { berdasarkan } \\
\text { bagiannya }\end{array}$ & Berhasil \\
\hline 3 & $\begin{array}{l}\text { Mengelola } \\
\text { data master }\end{array}$ & $\begin{array}{lr}\text { Bisa menambah, } \\
\text { mengubah, dan } \\
\text { menghapus data } \\
\text { master } \\
\text { aplikasi }\end{array}$ & Berhasil \\
\hline 4 & $\begin{array}{l}\text { Ubah status } \\
\text { validasi }\end{array}$ & $\begin{array}{lr}\text { Bagian wakasapras } \\
\text { dapat mengubah } \\
\text { status validasi } \\
\text { pengelolaan aset }\end{array}$ & Berhasil \\
\hline 5 & $\begin{array}{l}\text { Mengelola } \\
\text { perbaikan } \\
\text { aset }\end{array}$ & $\begin{array}{l}\text { Bisa menambah } \\
\text { dan megubah data } \\
\text { perbaikan aset }\end{array}$ & Berhasil \\
\hline 6 & $\begin{array}{l}\text { Ubah status } \\
\text { perbaikan } \\
\text { aset }\end{array}$ & $\begin{array}{l}\text { Bagian wakasapras } \\
\text { dan petugas dapat } \\
\text { mengubah status } \\
\text { perbaikan aset }\end{array}$ & Gagal \\
\hline 7 & $\begin{array}{l}\text { Mengelola } \\
\text { perawatan } \\
\text { aset }\end{array}$ & $\begin{array}{l}\text { Bisa menambah } \\
\text { dan megubah data } \\
\text { perawatan aset }\end{array}$ & Berhasil \\
\hline 8 & $\begin{array}{l}\text { Melakukan } \\
\text { perawatan } \\
\text { aset }\end{array}$ & $\begin{array}{lr}\text { Bagian wakasapras } \\
\text { dan petugas dapat } \\
\text { memilih } & \text { daftar } \\
\text { perawatan } & \text { aset } \\
\text { sesuai } & \text { dengan } \\
\text { kelompok } & \\
\text { barangnya } & \\
\end{array}$ & Berhasil \\
\hline 9 & $\begin{array}{l}\text { Menampilkan } \\
\text { detail } \\
\text { perawatan } \\
\text { aset }\end{array}$ & $\begin{array}{l}\text { Bagian wakasapras } \\
\text { dan petugas dapat } \\
\text { melihat detail } \\
\text { perawatan aset di } \\
\text { setiap aset yang } \\
\text { sedang dalam } \\
\text { perawatan }\end{array}$ & Berhasil \\
\hline 10 & $\begin{array}{l}\text { Mengelola } \\
\text { penghapusan } \\
\text { aset }\end{array}$ & $\begin{array}{l}\text { Bisa menambah } \\
\text { dan megubah data } \\
\text { penghapusan aset }\end{array}$ & Berhasil \\
\hline 11 & $\begin{array}{l}\text { Mencetak } \\
\text { laporan }\end{array}$ & 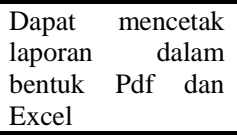 & Berhasil \\
\hline 12 & $\begin{array}{l}\text { Menampilkan } \\
\text { daftar aset }\end{array}$ & $\begin{array}{lr}\text { Pengguna dapat } \\
\text { melihat daftar aset } \\
\text { dan mengetahui } \\
\text { aset r berasal } \\
\text { darimana }\end{array}$ & Berhasil \\
\hline 13 & $\begin{array}{l}\text { Menampilkan } \\
\text { klasifikasi } \\
\text { aset }\end{array}$ & $\begin{array}{l}\text { Pengguna dapat } \\
\text { melihat klasifikasi } \\
\text { aset dan } \\
\text { mengetahui jenis } \\
\text { dari aset tersebut }\end{array}$ & Berhasil \\
\hline 14 & $\begin{array}{l}\text { Menampilkan } \\
\text { umur aset }\end{array}$ & $\begin{array}{l}\text { Pengguna dapat } \\
\text { melihat umur aset } \\
\text { dan mengetahui } \\
\text { umur berjalan aset }\end{array}$ & Berhasil \\
\hline
\end{tabular}

\section{KESIMPULAN}

Kesimpulan yang dapat di ambil dari aplikasi Manajemen Aset Berbasis Web pada SMA Hang Tuah 4 Surabaya adalah sebagai berikut:

1. Aplikasi dapat membantu pihak sekolah untuk melakukan pencatatan aset, pengelolaan aset, perbaikan aset, perawatan aset, penghapusan atau pemutihan asset.

2. Aplikasi dapat menghasilkan Laporan Data Aset, Laporan Hasil Pengelolaan Aset yang didapatkan dari proses rekap transaksi Perbaikan, Perawatan, dan Penghapusan Aset.

3. Aplikasi ini telah diuji coba menggunakan Black Box Testing yang secara fungsional 92.8\% program aplikasi dapat berjalan dengan baik.

\section{SARAN}

Aplikasi Manajemen asset Berbasis Web pada SMA Hang Tuah 4 Surabaya ini masih memiliki kekurangan. Adapun saran yang dapat disampaikan kepada peneliti berikutnya adalah sebagai berikut :

1. Penambahan fitur penyusutan asset sesuai dengan umur dan kualitas aset.

2. Tersedianya aplikasi dalam bentuk mobile apps.

3. Penambahan fitur yang dapat memberikan informasi mengenai perkiraan biaya yang dapat dianggarkan oleh pihak sekolah untuk keperluan manajemen aset.

\section{Ucapan Terimakasih}

Terimakasih disampaikan pada pihak-pihak yang membantu dalam mendukung penyelesaian penelitian ini yaitu Universitas Dinamika dan SMA Hang Tuah 4 Surabaya.

\section{DAFTAR PUSTAKA}

[1] S. Wahyuni, Pengantar Manajemen Aset. Makassar: Nas Media Pustaka, 2020.

[2] Sansan, "Kode Barang dan Fungsinya dalam Persediaan," Keysoft Web, 2019. https://keysoft.co.id/kode-barangfungsinya-dalam-persediaan/. 
Rahmat Julianto Putra, dkk/ Journal of Technology and Informatics (JoTI), Vol.2, No.2, April 2021, Hal 65-71

[3] F. . Riovaldo, Maisyaroh, and A. Sunandar, "Penaksiran Nilai Aset dan Manajemen Aset Di Sekolah Menengah Kejuruan," JAMP J. Adm. dan Manaj. Pendidik., vol. 1, no. September, pp. 156166, 2012.

[4] J. Ariska et al., "Rancang Bangun Sistem Informasi Manajemen Aset Sekolah Menggunakan Teknik Labelling QR Code ( Studi Kasus: Man 2 Model Pekanbaru )," J. Rekayasa Dan Manaj. Sist. Inf., vol. 2, no. 2, pp. 127-136, 2016.

[5] W. Mudiar and U. Hidayat, "Sistem Informasi Manajemen Asset Berbasis Web Pada Perbanas Institute," Inf. Manag. Educ. Prof., 2019.

[6] F. Sani, "Perancangan Sistem Informasi Manajemen Aset dan Inventaris SMK N 7 Padang," Universitas Negeri Padang, 2014.

[7] R. D. S. Poetro, "Sistem Informasi Aset berbasis Web Studi Kasus SD Negeri 1 Gatak Delanggu," Universitas Muhammadiyah Surakarta, 2017.

[8] J. Riyanto, "Rancang Bangun Sistem Informasi Manajemen Aset Pada Universitas Pamulang Berbasis Web," $J$. Inform. Univ. Pamulang, 2019.

[9] S. R. Vallabhaneni, Wiley CIAExcel Exam Review 2015, Part3: Internal Audit Knowledge Elements. Canada: John Willey \& Sons., 2015.

[10] Pressman, Rekayasa Perangkat Lunak: Pendekatan Praktisi Buku I. Yogyakarta: ANDI, 2015. 